\title{
POLITICS AND SOCIAL FORCES IN CHILEAN DEVELOPMENT
}





\section{POLITICS AND SOCIAL FORCES IN CHILEAN DEVELOPMENT \\ James Petras}

UNIVERSITY OF CALIFORNIA PRESS

BERKELEY AND LOS ANGELES 1969 
UNIVERSITY OF CALIFORNIA PRESS

BERKELEY AND LOS ANGELES, CALIFORNIA

UNIVERSITY OF CALIFORNIA PRESS, LTD.

LONDON, ENGLAND

COPYRIGHT (C) 1969 , by

THE REGENTS OF THE UNIVERSITY OF CALIFORNLA

LIBRARY OF CONGRESS CATALOG CARD NUMBER: 69-15904

PRINTED IN THE UNITED STATES OF AMERICA 
TO BETTY, STEFAN

AND ANNE MARIE 
